\title{
Dynamic response of masonry minarets strengthened with Fiber Reinforced Polymer (FRP) composites
}

\author{
A. C. Altunişik \\ Karadeniz Technical University, Department of Civil Engineering, 61080, Trabzon, Turkey \\ Received: 3 June 2011 - Revised: 15 June 2011 - Accepted: 16 June 2011 - Published: 20 July 2011
}

\begin{abstract}
Engineering structures strengthened with FRP composites are gaining popularity, and there is a growing need to understand and compare the behavior of these structures before/after FRP composite strengthening. In this paper, it is aimed to determine the dynamic response of masonry minarets before/after FRP composite strengthening. An İskenderpaşa historical masonry minaret dating back to XVI century with a height of $21 \mathrm{~m}$ located in Trabzon, Turkey was selected as an application. Firstly, 3-D finite element model of the minaret was constituted using ANSYS software. Then, an analytical model of the minaret was analyzed using the 1992 Erzincan earthquake record, which occurred near the area, to determine the dynamic behavior. After this, the cylindrical body of the minaret was strengthened with FRP composite using different configurations and dynamic analyses were performed. Finally, dynamic responses of the minaret before and after FRP composite strengthening, such as displacements and maximum-minimum principal stresses, were compared. At the end of the study, it is seen that displacements had increased along the height of the minaret, maximum and minimum principal stresses occur at the region of transition segment and cylindrical body for all analyses. Also, it is seen from the earthquake analyses that FRP strengthening is very effective on the dynamic responses of the minaret.
\end{abstract}

\section{Introduction}

Historical structures are our cultural values left behind by thousands of years' cultural accumulation. They pass our identity and civilization on to the next generations. Conservation of historical structures and carrying them into the

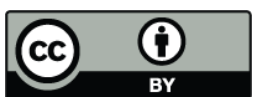

Correspondence to: A. C. Altunişik (ahmetcan8284@hotmail.com) future are our inevitable duty. In the last decade, the conservation, strengthening and the structural safety assessment of historical masonry structures such as minarets, towers, bridges and buildings have become of increasing concern, probably as a consequence of some dramatic events registered in the world.

Tall structures by their nature are computationally intensive to analyze. They consist of thousands of degrees of freedom and when subjected to strong ground motion from a source, exhibit a very complex response (Krishnan, 2004). Minarets are one of the thin and tall engineered structures. These are distinctive architectural features of Islamic mosques and generally tall spires with onion shaped or conical crowns. Minarets are used for calling out the azan five times each day by a muezzin in order to signal people to come to prayers.

Polymeric composites are advanced engineering materials with the combination of high-strength, high-stiffness fibers, and low-cost, light-weight, environmentally resistant matrices. Fiber reinforced polymers (FRPs) are a class of advanced composite materials that originated from the aircraft and space industries. They have been used widely in the medical, sporting goods, automotive and small ship industries. FRP has high strength to weight ratios, and excellent resistance to corrosion and environmental degradation (Mosallam, 2007; Zaki, 2011). It is very flexible and forms all kinds of shapes and is easy to handle during construction. With the increasing demand for infrastructure renewal and the decreasing cost for composite manufacturing, FRP materials began to be extensively used in civil engineering in the 1980s and continue to expand in recent years.

In the literature, there is more paper exist about the structural behavior of engineering structures before and after FRP composite strengthening. Stierwalt and Hamilton (2005) examined the creep behavior of masonry walls strengthened with FRP composites compared to that of conventional reinforcement. Eight full-scale unreinforced concrete masonry

Published by Copernicus Publications on behalf of the European Geosciences Union. 


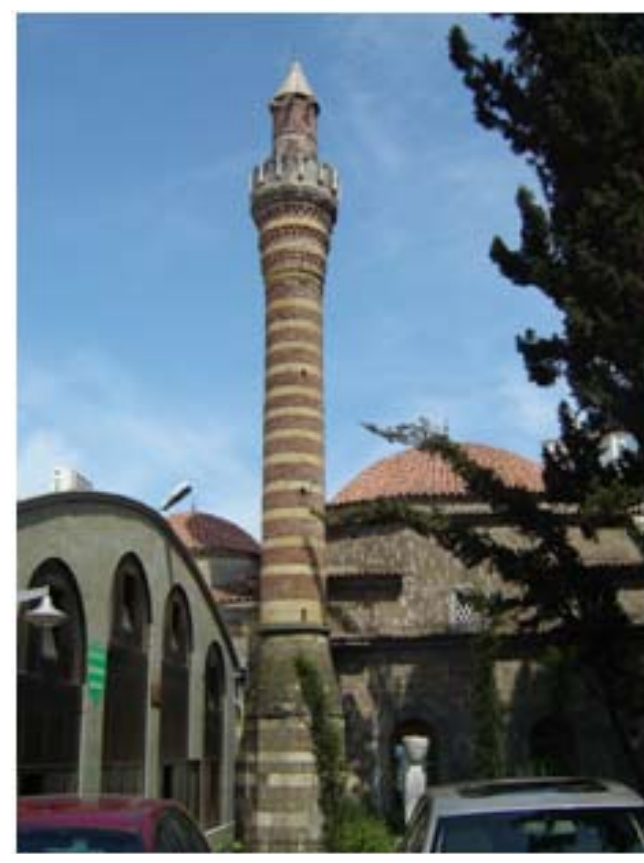

Fig. 1. Some views of İskenderpaş, a historical masonry minaret

walls were constructed for testing long-term deflections outof-plane. Mosallam (2007) presented the results of a study focused on evaluating the out-of-plane flexural behavior of two FRP composite systems for strengthening unreinforced red brick masonry walls. Ghosh and Karbhari (2007) provided details of an investigation into the strengthening efficiency of FRP- rehabilitated bridge deck slabs through tests conducted on slab sections cut from a bridge just prior to demolition. Al-Saidy et al. (2008) conducted an analytical parametric study on the behavior of steel-concrete composite beam that has been strengthened with CFRP plates. In addition, the effect of girder damage on the overall load distribution of a typical short span composite bridge has been investigated for various load cases. Mortazaei et al. (2010) determine the seismic response of FRP strengthened typical existing RC buildings subjected to near-fault ground motions. Kim and Harries (2010) emerged a modeling approach to predict the behavior of timber beams strengthened with FRP composites. A 3-D finite element analysis model is formulated, based on the orthotropic constitutive characteristics of timber species. Zaki (2011) studied the behavior of FRP strengthened circular columns under combined axial loads and biaxial bending moments. Tao et al. (2011) performed a series of laboratory tests investigating the behavior of a large model masonry arch bridge repaired with externally bonded FRP composites on its intrados. A two-span, single-ring semi-circular brick arch bridge was selected for this study, complete with fill material. Besides these studies, there is not more paper exist only a few paper (not enough for literature) exist relate to dynamic responses of FRP strengthened thin and tall historical masonry structures such as minarets.

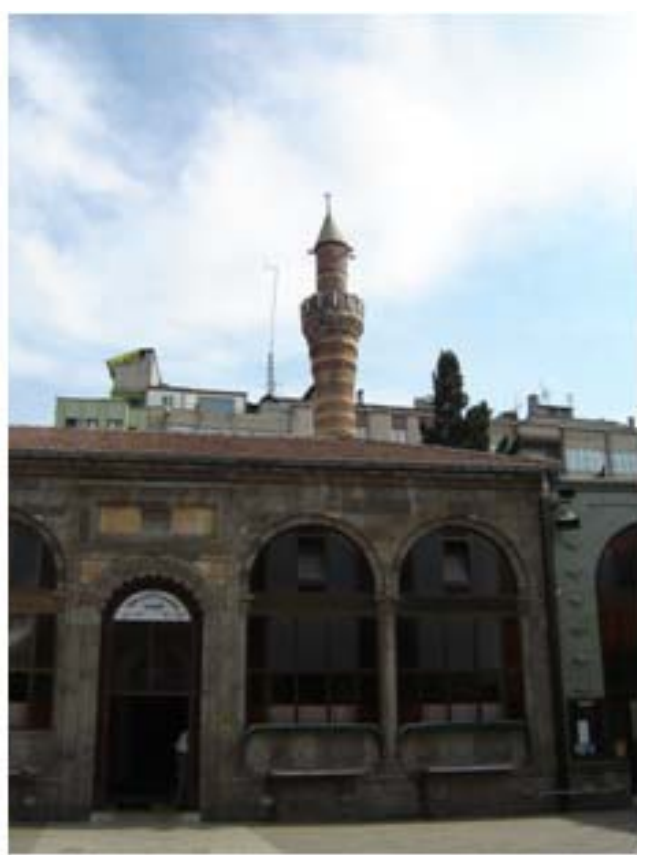

The objective of this paper is to calculate the detailed dynamic responses of a historical masonry minaret and compare them to an FRP composite counterpart. For this purpose, the İskenderpaşa masonry minaret located in the city center of Trabzon, Turkey is selected as a case study. A three-dimensional finite element model of the minaret has been created by ANSYS software and structural analysis has been performed. Then, the cylindrical body of the minaret was strengthened with FRP composite using different configurations and dynamic analyses were performed. At the end of the study, dynamic responses before and after FRP composite strengthening such as displacements and maximumminimum principal stresses are compared.

\section{2 İskenderpaşa historical masonry minaret}

The İskenderpaşa historical masonry minaret has a total height of $20.5 \mathrm{~m}$ and is located in a heavy traffic and crowded area in Trabzon city center, Turkey. The minaret was built by a governor of a Trabzon (İskender Pasha) in the XVI century. Stones and bricks were used together in construction of the minaret with beautiful decorations under the balcony. Scarecrows are decorated with emblems and circular motifs. Figure 1 shows some views of the İskenderpaşa historic masonry minaret. As in Fig. 1, the minaret is very thin and tall with one balcony on its body.

Minarets basically consist of three parts; a base, a shaft, and a gallery. The base is foundation of the minaret. The shaft is the thin, slim body of the minaret and stairs are place cylindrically in the shaft to provide the necessary structural 

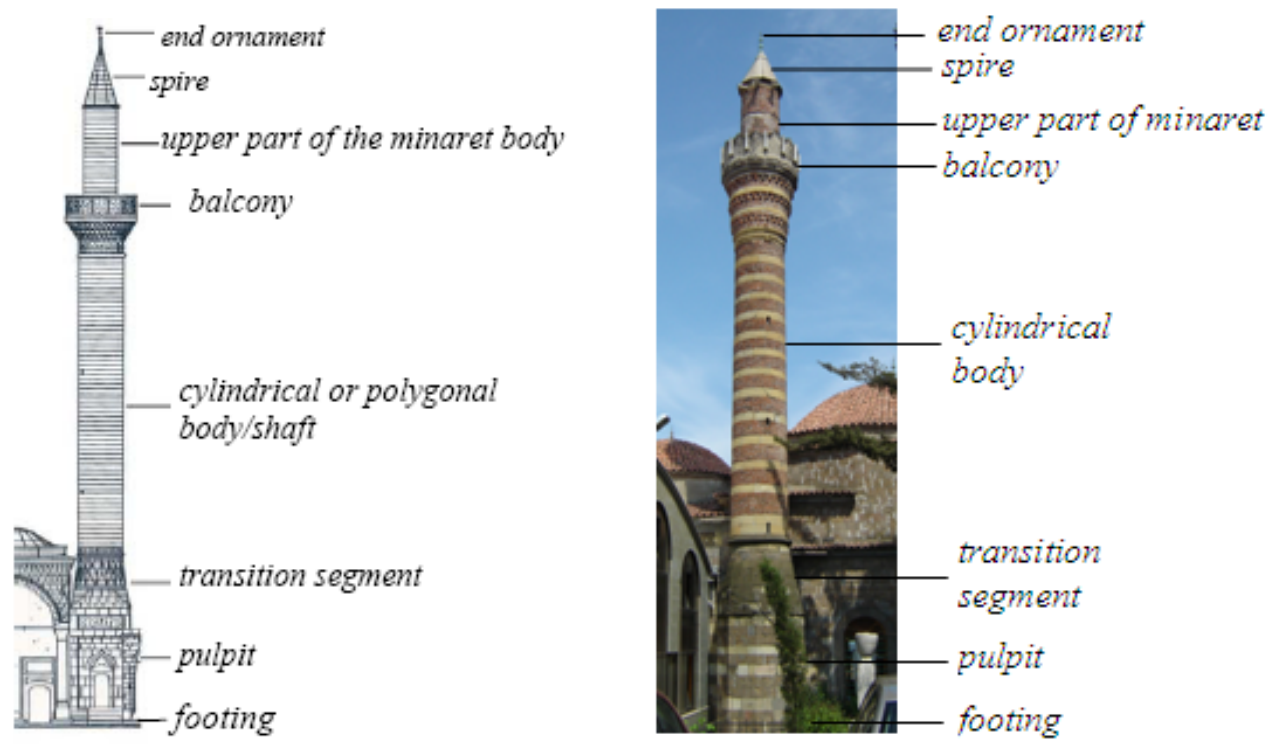

Fig. 2. Segments of the classical Ottoman style and İskenderpaşa minarets.
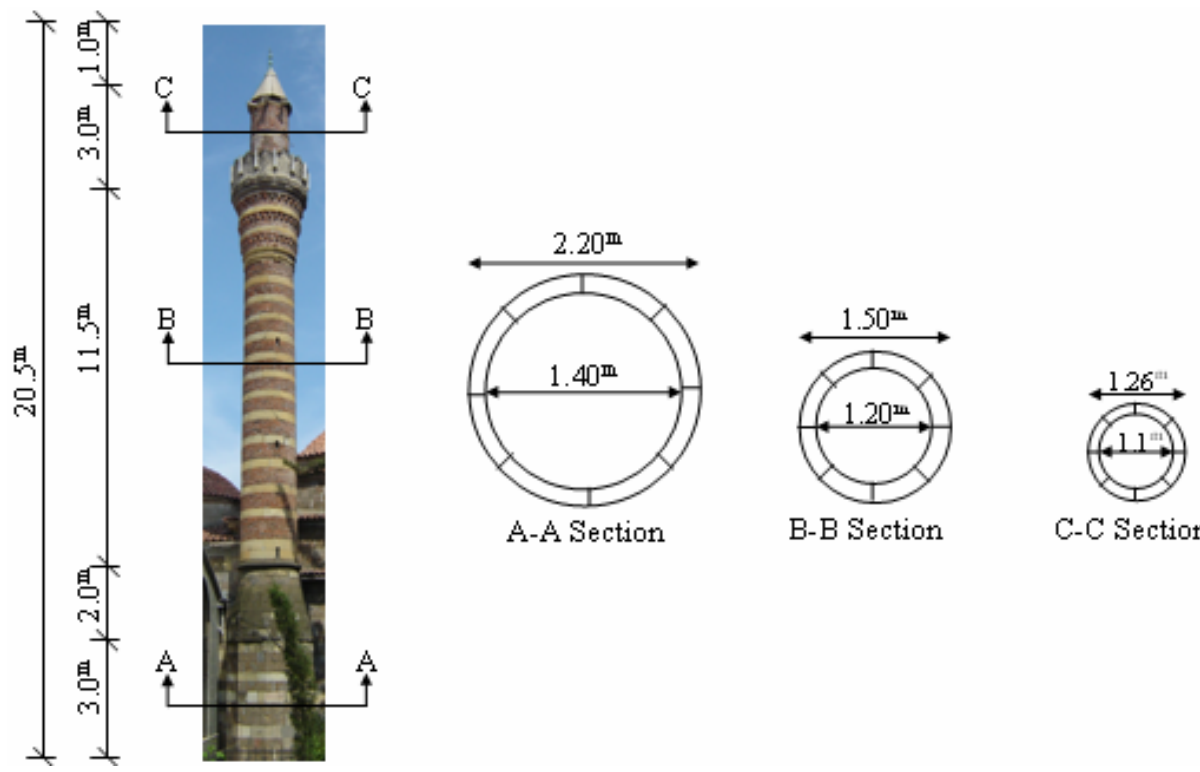

B-B Section

C-C Section

Fig. 3. Geometrical properties of the minaret.

support for the elongated shafts. The gallery is a balcony that encircles the upper section where the muezzins call out to prayer. It is covered by a roof-like canopy and adorned with ornamentation such as decorative bricks and decorated with painted tile, cornices, arches and inscriptions. Similar to classical Ottoman style minarets, the İskenderpaşa minaret consisting of a footing as a base; pulpit, transition segment, cylindrical or polygonal body as a shaft; balcony; upper part of the minaret body; spire; and the end an ornament, as shown in Fig. 2.
General arrangement drawings of the entire minaret are shown in Fig. 3 where the geometrical properties of the minaret are given. In addition to these dimensions, there is a $0.20 \mathrm{~m}$ diameter stone block in the middle of the minaret. Around the stone block, there are 83 stairs from the floor to the balcony with $0.20 \mathrm{~m}$ step height. Each stair has an inner and outer radius of $0.10 \mathrm{~m}$ and $0.60 \mathrm{~m}$, respectively. 

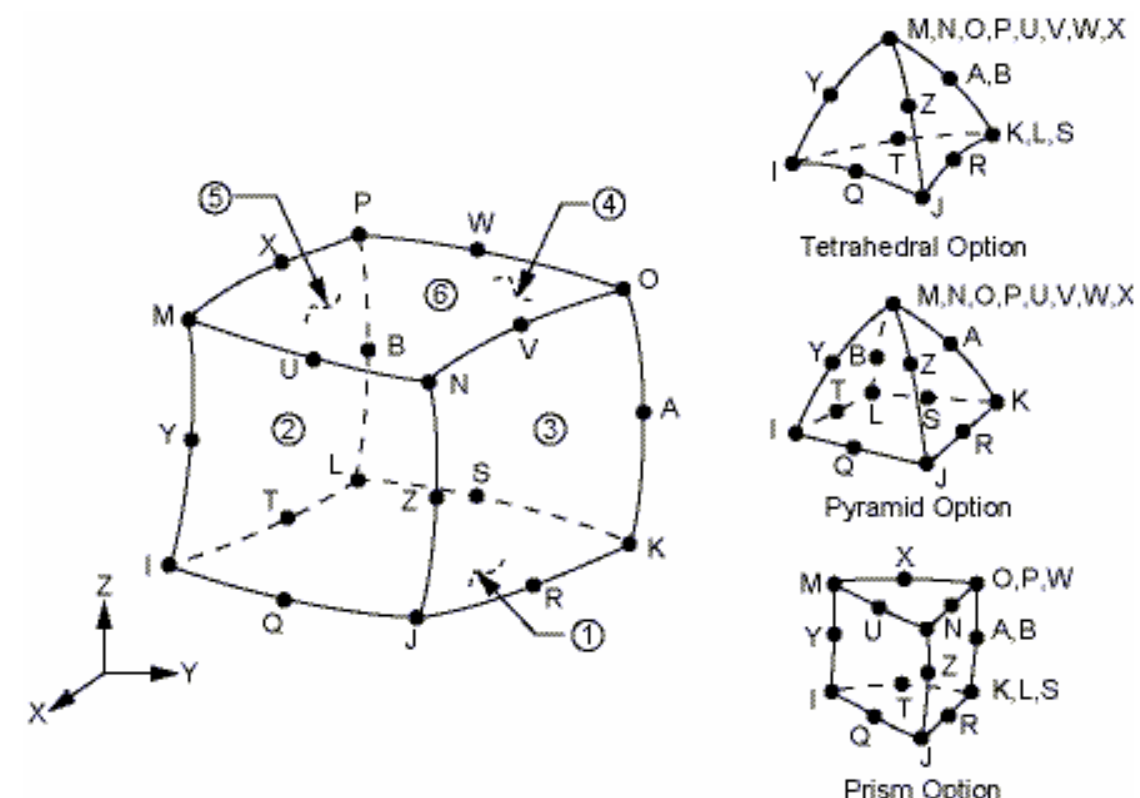

Fig. 4. A schematic view and properties of the SOLID186 element.

Table 1. Material properties used in analyses of the minaret.

\begin{tabular}{llllll}
\hline Elements & \multicolumn{5}{c}{ Material Properties } \\
\cline { 2 - 6 } & Directional & $\begin{array}{l}\text { Modulus of Elasticity } \\
\text { Symmetry Type }\end{array}$ & $\begin{array}{l}\text { Poisson's Ratio } \\
\left(\mathrm{N} \mathrm{m}^{-2}\right)\end{array}$ & $\begin{array}{l}\text { Mass per unit } \\
\text { Vol. }\left(\mathrm{kg} \mathrm{m}^{-3}\right)\end{array}$ & $\begin{array}{l}\text { Shear Modulus } \\
\left(\mathrm{N} \mathrm{m}^{-2}\right)\end{array}$ \\
\hline Minaret & Isotropic & $2.00 \mathrm{E} 9$ & 0.20 & 2169 & - \\
FRP Composite & Orthotropic & $3.3 \mathrm{E} 10$ & 0.25 & 1790 & $1.32 \mathrm{E} 10$ \\
\hline
\end{tabular}
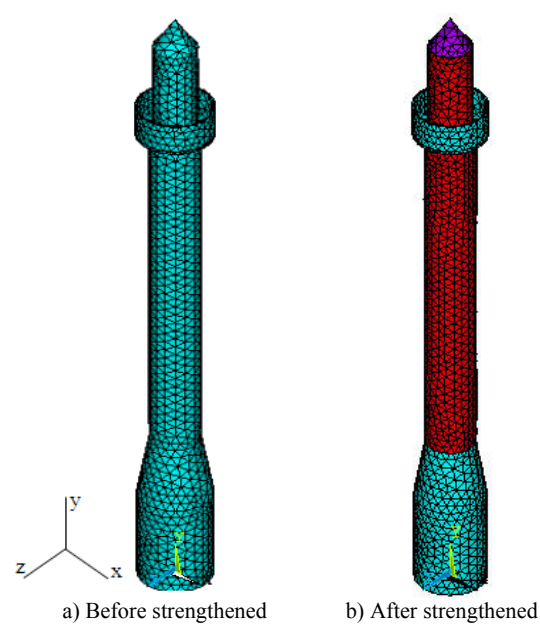

Fig. 5. 3-D finite element models of the minaret before and after FRP composite strengthening including concrete block and stairs

\section{Finite element modeling}

Three-dimensional finite element models of the minaret before and after FRP composites strengthening were developed using the ANSYS software (ANSYS, 2008). This program can be used for linear and non-linear, static and dynamic analyses of 3-D model structures. In this paper, based on its physical and mechanical properties, the program was used to determine the dynamic behavior of the minaret. Convergence studies about element size were performed and the optimum element sizes were chosen for both models. In the finite element models of the minaret, SOLID186 elements were used which exhibited quadratic displacement behavior. The element had 20 node and three degrees of freedom per node: translations in the nodal $\mathrm{x}, \mathrm{y}$, and $\mathrm{z}$ directions. In addition, it had the capability of plasticity, elasticity, creep, stress stiffening, large deflection, and large strains. A schematic view of the SOLID186 element is shown in Fig. 4. When the structural solid geometry property of the SOLID186 element is examined, it can be seen that the elements appear to 


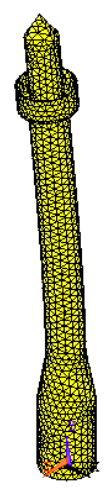

$1^{\text {st }}$ Mode $\mathrm{f}_{1}=1.09 \mathrm{~Hz}$

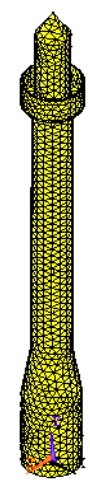

$2^{\text {nd }}$ Mode $\mathrm{f}_{2}=1.09 \mathrm{~Hz}$

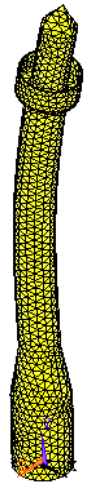

$3^{\text {rt }}$ Mode $\mathrm{f}_{3}=5.59 \mathrm{~Hz}$

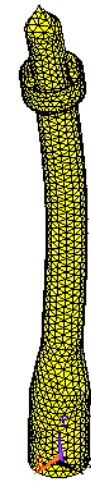

$4^{\text {th }}$ Mode $\mathrm{f}_{4}=5.59 \mathrm{~Hz}$

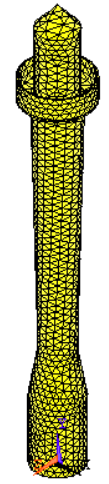

$5^{\text {th }}$ Mode $\mathrm{f}_{5}=9.78 \mathrm{~Hz}$
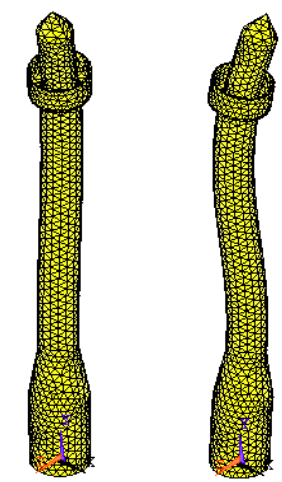

$6^{\text {th }}$ Mode $\quad 7^{\text {th }}$ Mode $\mathrm{f}_{6}=12.16 \mathrm{~Hz} \quad \mathrm{f}_{7}=12.16 \mathrm{~Hz}$

a) Before FRP composite strengthening

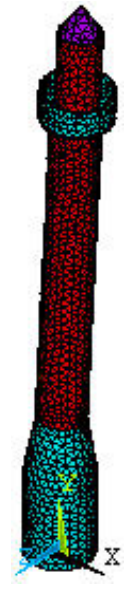

$1^{\text {st }}$ Mode $\mathrm{f}_{1}=1.61 \mathrm{~Hz}$

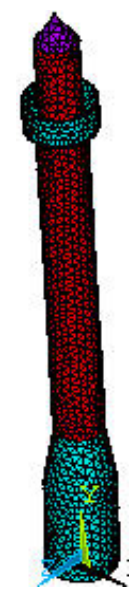

$2^{\text {nd }}$ Mode $\mathrm{f}_{2}=1.61 \mathrm{~Hz}$

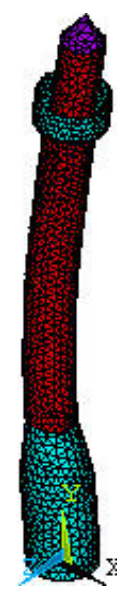

$3^{\text {rt }}$ Mode $\mathrm{f}_{3}=10.59 \mathrm{~Hz}$

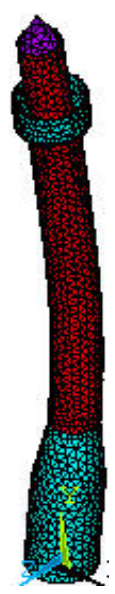

$4^{\text {th }}$ Mode $\mathrm{f}_{4}=10.61 \mathrm{~Hz}$

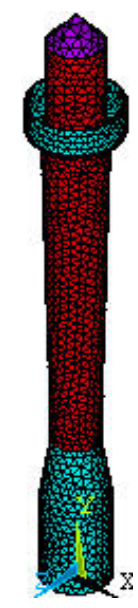

$5^{\text {th }}$ Mode $\mathrm{f}_{5}=17.73 \mathrm{~Hz}$
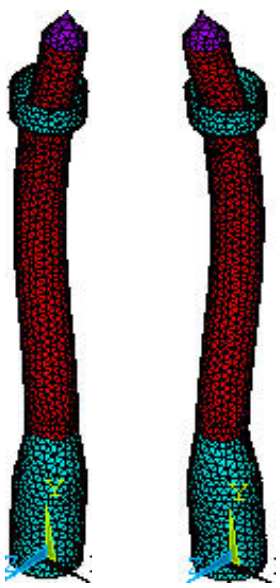

$6^{\text {th }}$ Mode $\quad 7^{\text {th }}$ Mode $\mathrm{f}_{6}=19.06 \mathrm{~Hz} \quad \mathrm{f}_{7}=19.07 \mathrm{~Hz}$

b) After FRP composite strengthening

Fig. 6. Natural frequencies and corresponding mode shapes of the minaret before and after FRP composite strengthening.

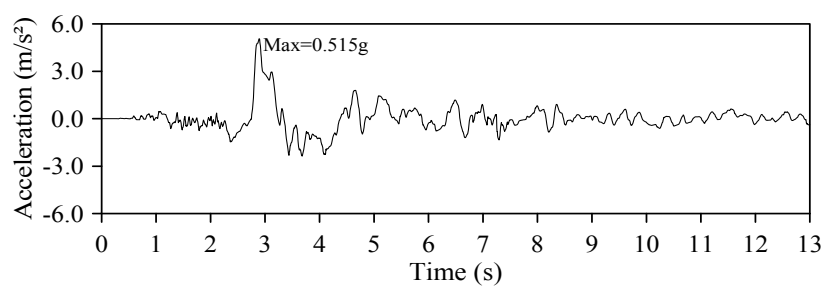

Fig. 7. The time-history of ground motion acceleration of 1992 Erzincan. earthquake.

be made of tetrahedral, pyramid or prism options in the finite element mesh model of the minaret.

Determination of material properties and boundary conditions that must be taken into account in the finite element analysis is very important for thin and tall structures such as minarets. But, removing test samples from the historical masonry structures such as minarets was not allowed by the related institution. So, initial material properties were taken from the literature (Frunzio et al., 2001; Doangün et al., 2006; Gentile and Saisi, 2007; Bayraktar et al., 2008; Bayraktar et al., 2009). For the structural strengthening of the minaret, woven carbon fiber fabric material was used. This material can be used for strengthening of reinforced concrete and masonry structures, brickwork and timber in case of flexural and shear load due to increase of loading capacity, changes of building utilisation, repair of defects, prevention of defects caused by earthquakes and meeting of changed standards. The values of the material properties used in analyses of the minaret are given in Table 1. The minaret was taken in place rock soil. As initial boundary 


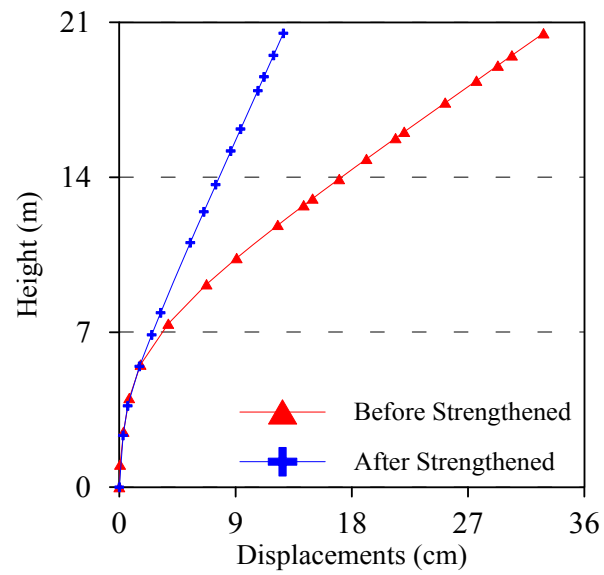

Fig. 8. Variation of maximum displacements along to the height of the minaret at the time of maximum response before and after FRP composite strengthening.
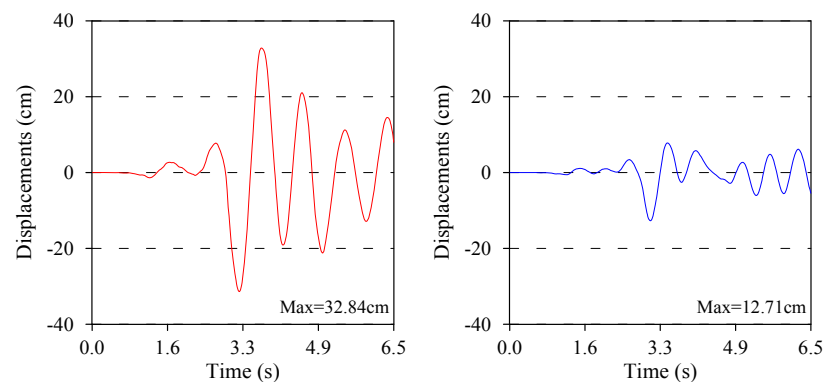

Fig. 9. Time histories of maximum displacements at the top of minaret for both analyses.

conditions, all of the degrees of freedom under the footing part of the minaret are selected as fixed.

The 3-D finite element models of the minaret before and after FRP composite strengthening including concrete block and stairs are shown in Fig. 5. According to the convergence studies, the optimum mesh size is chosen as $30 \mathrm{~cm}$ and $20 \mathrm{~cm}$ before and after FRP composite strengthening, respectively. The mesh size may be reduced. But, when the element and node numbers are increased, the analyses duration and total volume increase. In the FRP composite strengthening model, the thickness of FRP is very small when compared with the thickness of cylindrical body of the minaret. Thus, $20 \mathrm{~cm}$ mesh size is used in the finite element analyses after FRP composite strengthening. Therefore, 18620 and 95841 SOLID186 elements are used in the finite element models. In the composite strengthening model, the cylindrical body of the minaret is wrapped by four layers of FRP and total thickness of the FRP is chosen as $6 \mathrm{~mm}$. Element stiffness behavior is considered as tensile and compressive. Extra displacement shapes are included, but extra stress outputs are not considered.
A total of 7 natural frequencies of the minaret before and after FRP composite strengthening were obtained with a range between $1.09-12.16 \mathrm{~Hz}$ and $1.61-19.07 \mathrm{~Hz}$, respectively. When the first seven modes were examined for both analyses, the first four modes of the minaret are horizontal modes in the $\mathrm{z}$ and $\mathrm{x}$ directions, the fifth mode is a torsional mode and last two modes are horizontal modes in the $\mathrm{z}$ and $\mathrm{x}$ directions, as seen in Fig. 6.

\section{Dynamic response of the minaret}

Linear transient analyses of the İskenderpaşa historical masonry minaret before and after FRP composite strengthening were performed using ERZIKAN/ERZ-NS component of 1992 Erzincan earthquake $\left(M_{\mathrm{w}}=6.9\right)$ ground motion (Fig. 7) (PEER, 2007). The element matrices were computed using the Gauss numerical integration technique (Bathe, 1996). The Newmark method was used in the solution of the equations of motion.

Rayleigh damping constants were calculated between the first horizontal mode of the minaret and the seventh mode, assuming a $5 \%$ damping ratio. Alpha and Beta coefficients before and after FRP composite strengthening were calculated as 0.616 and $0.00146 ; 0.928$ and 0.00082 , respectively. Because of the large memory required for the analyses, only the first 6.5 second of the ground motions, which is the effective duration, was taken into account in the calculations.

The horizontal displacements along to the height of the minaret at the time of maximum response before and after FRP composite strengthening are given in Fig. 8. It is seen that the displacements increase along the height of the minaret and that the maximum displacement (at the top of the minaret) is obtained before and after FRP composite strengthening as 32.84 and $12.71 \mathrm{~cm}$, respectively. Also, the time histories of the horizontal displacements (with a peak value of) $32.84 \mathrm{~cm}$ and $12.71 \mathrm{~cm}$ for both analyses at the top of the İskenderpaşa historical masonry minaret subjected to the Erzincan ground motion are presented in Fig. 9.

Figure 10 points out the contours of maximum horizontal displacement corresponding to both analyses. These displacement contours represent the distribution of the peak values reached by the maximum displacement at each point within the section.

The time histories of the maximum and minimum principal stresses of the minaret subjected to the Erzincan 1992 earthquake are plotted in Fig. 11. As shown in Fig. 11, the highest maximum and minimum principle stresses occurred before FRP composite strengthening. Also, maximum and minimum principal stress contours of the minaret before and after FRP composite strengthening are given in Figs. 12 and 13. These stress contours represent the distribution of the peak values reached by the maximum principal stress at each point within the section. It is clearly seen from Figs. 12 and 13 that FRP composite is very effective in the principal stresses. 

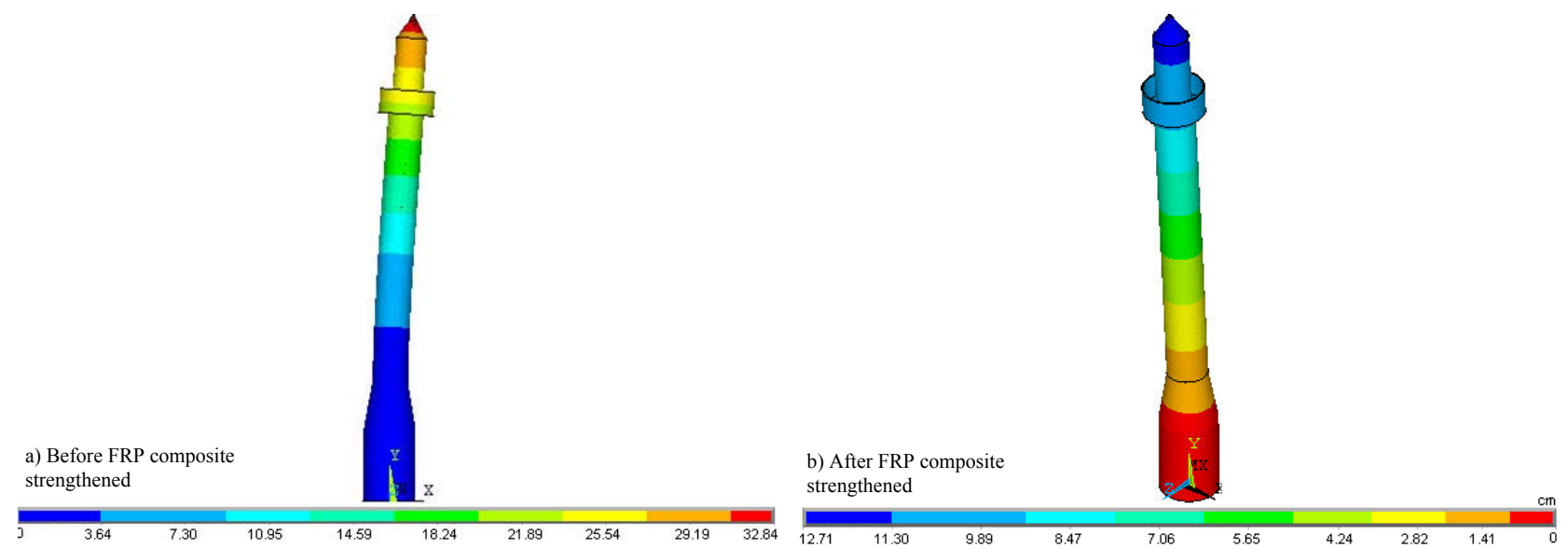

Fig. 10. Maximum displacement contours of İskenderpaşa historical minaret.
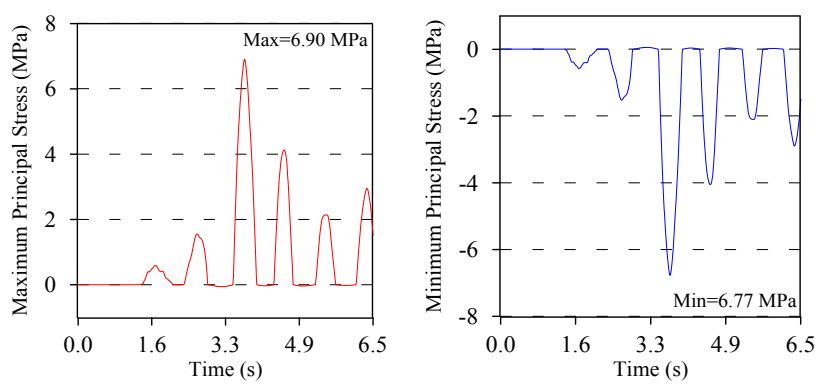

(a) Before FRP composite strengthened
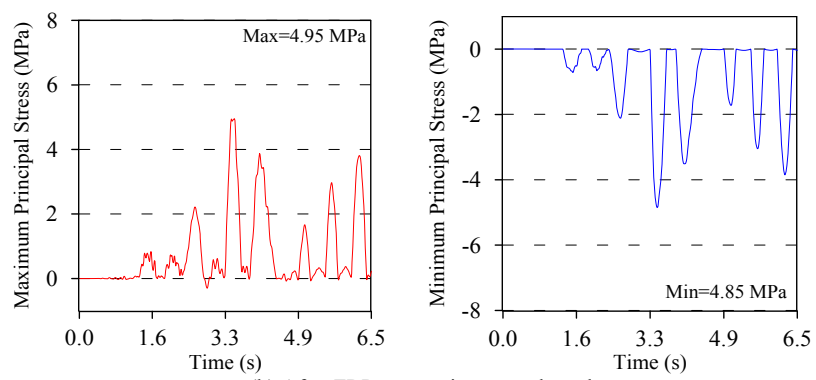

(b) After FRP composite strengthened

Fig. 11. The time histories of maximum and minimum principal stresses of the İskenderpaşa historical minaret before and after FRP composite strengthening.

\section{Conclusions}

This paper aimed to determine the dynamic response of masonry minarets before and after FRP composite strengthening. The İskenderpaşa historical masonry minaret with a height of $21 \mathrm{~m}$ located in Trabzon, Turkey was selected as an application. A 3-D finite element model of the minaret was constituted using ANSYS software and dynamic behavior was determined using 1992 Erzincan earthquake record before and after the FRP composite strengthening. The following observations can be deduced from the study:
- From the modal analyses of the minaret, a total of 7 natural frequencies before and after FRP composite strengthening were obtained with a range between $1.09-12.16 \mathrm{~Hz}$ and $1.61-19.07 \mathrm{~Hz}$, respectively. When the first seven modes are examined for both analyses, the first four and last two modes are horizontal modes in the $\mathrm{z}$ and $\mathrm{x}$ directions and the fifth mode is a torsional mode. It is seen that FRP composite brought stiffness into the structural system.

- Rayleigh damping constants are calculated between the first horizontal mode of the minaret and the seventh mode, assuming a $5 \%$ damping ratio. Alpha and Beta coefficients before and after FRP composite strengthening are calculated as 0.616 and $0.00146 ; 0.928$ and 0.00082 , respectively.

- An earthquake analysis of the minaret before and after FRP composite strengthening was performed using the 1992 Erzincan ground motion. It can be seen from the analysis that horizontal displacements increased along to the height of the minaret for both analyses and that the maximum displacement (at the top of the minaret) was obtained before and after FRP composite strengthening as 32.84 and $12.71 \mathrm{~cm}$, respectively.

- Maximum and minimum principal stresses occurred at the region between the transition segment and the cylindrical body before FRP composite strengthening, and they are equal to 6.90 and $-6.77 \mathrm{MPa}$, respectively. Therefore, it is likely that probable damages and cracks due to earthquake loads can occur at the region between the transition segment and the cylindrical body.

- To eliminate the probable damages and cracks, the cylindrical body of the minaret was strengthened with FRP composite and dynamic analyses were performed. FRP can be applied to the circular surfaces. The pulpit 


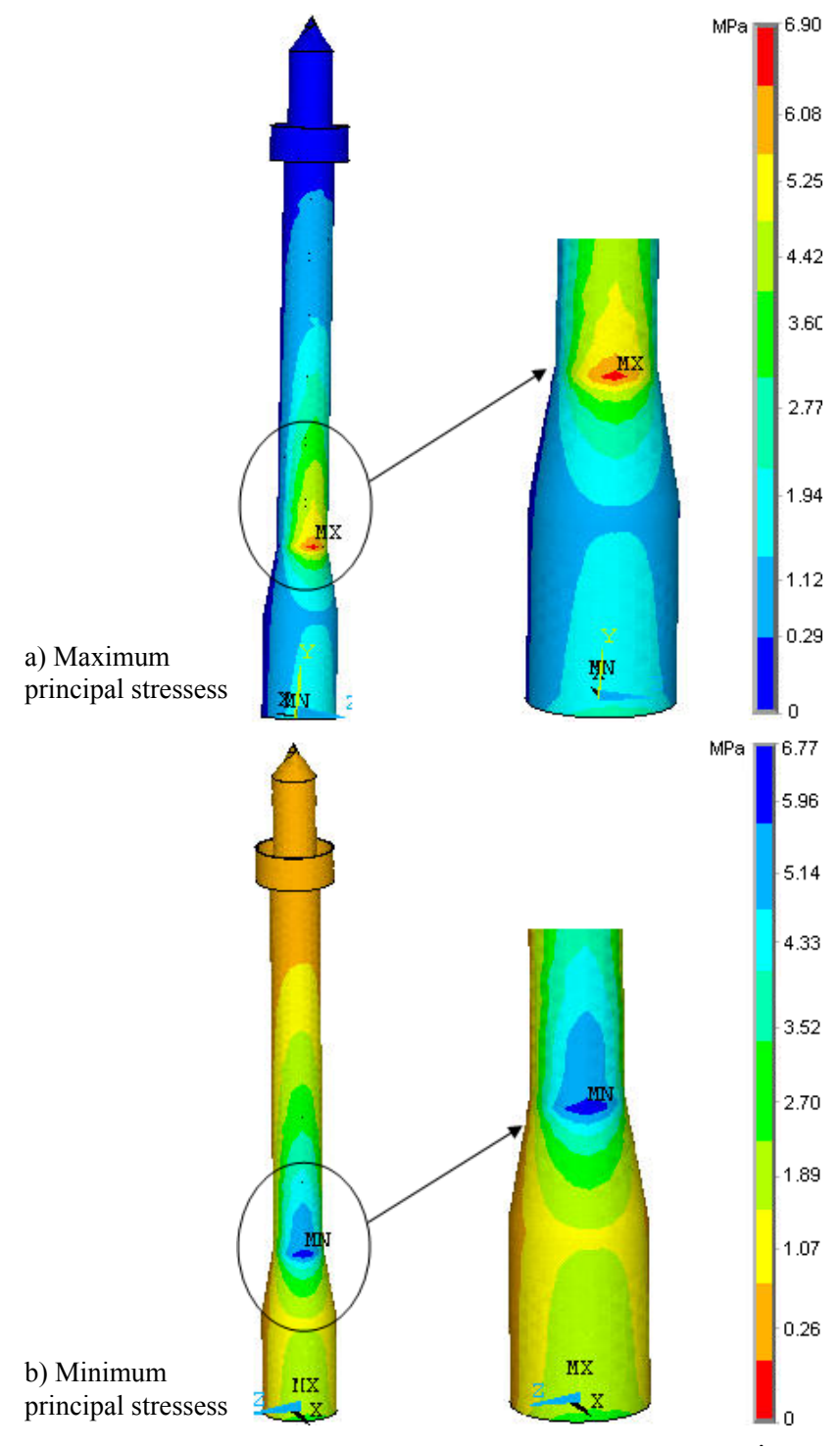

Fig. 12. Maximum and minimum principal stress contours of the İskenderpaşa historical minaret obtained before FRP composite strengthening

has a polygon surfaces and the transition segment has a variable polygon surfaces. So, only the cylindrical body of the minaret was wrapped by FRP. From the analyses, it is seen that maximum and minimum principal stresses were obtained as 4.95 and $-4.85 \mathrm{MPa}$, respectively.

- It is seen from the study that FRP composite strengthening is very effective in the dynamic response of the historical minaret. To determine the static, dynamic, linear and nonlinear structural behavior of the historical masonry structures such as bridges, minarets, belltowers, dams, buildings, which are our cultural values that left behind by thousands of years' cultural accumu-

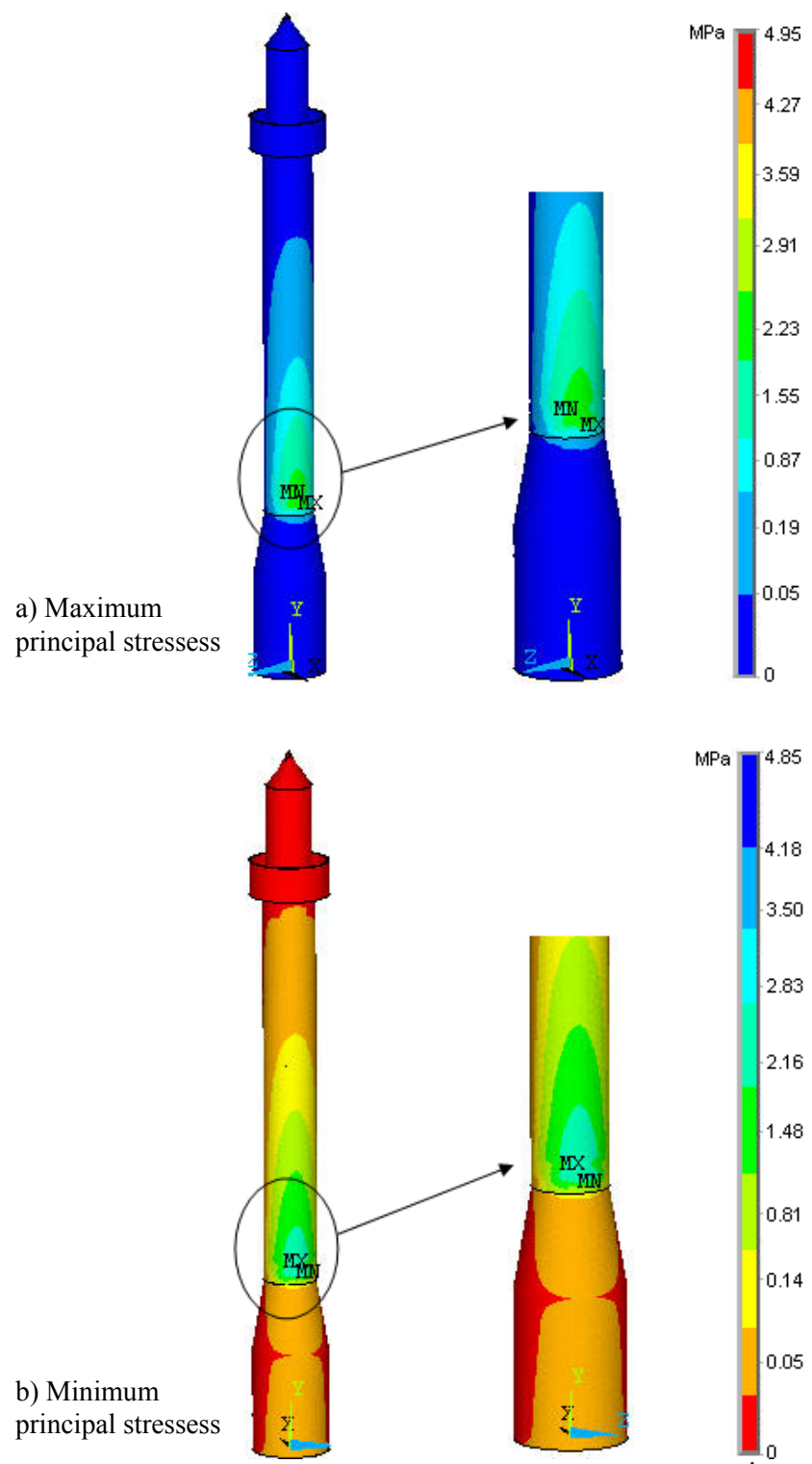

Fig. 13. Maximum and minimum principal stress contours of the İskenderpaşa historical minaret obtained after FRP composite strengthening

lation, FRP composite strengthening should be considered and the responses should be compared before the FRP composite strengthening.

Edited by: M. E. Contadakis

Reviewed by: two anonymous referees 


\section{References}

Al-Saidy, A. H., Klaiber, F. W., Wipf, T. J., Al-Jabri, K. S., and Al-Nuaimi, A. S.: Parametric study on the behavior of short span composite bridge girders strengthened with carbon fiber reinforced polymer plates, Constr. Build. Mater., 22, 729-737, doi:10.1016/j.conbuildmat.2007.01.020, 2008.

ANSYS V10.1.3.: Swanson Analysis System, Pennsylvania, US, 2008.

Bathe, K. J.: Finite Element Procedures in Engineering Analysis, Englewood Cliffs, New Jersey, Prentice-Hall, 1996.

Bayraktar, A, Altunişik, A. C., Sevim, B., Türker T, and Akköse M, Coşkun, N.: Modal Analysis, Experimental Validation and Calibration of a Historical Masonry Minaret, J. Test. Eval., 36, 516-524, doi:10.1520/JTE101677, 2008.

Bayraktar, A., Birinci, F., Altunişik, A. C., Türker, T, and Sevim, B.: Finite Element Model Updating of Senyuva Historical Arch Bridge using Ambient Vibration Tests, Balt. J. Road Bridge E., 4, 177-185, doi:10.3846/1822-427X.2009.4.177-185, 2009.

Doğangün, A., Acar, R., Livaoğlu, R., and Tuluk, Öİ.: Performance of masonry minarets against earthquakes and winds in Turkey, 1st International Conference on Restoration of Heritage Masonry Structures, Cairo, Egypt, 2006.

Frunzio, G., Monaco, M., and Gesualdo, A.: 3-D FEM analysis of a Roman Arch Bridge, Historical Constructions, 591-598, 2001.

Gentile, C. and Saisi, A.: Ambient vibration testing of historic masonry towers for structural identification and damage assessment, Constr. Build. Mater., 21, 1311-1321, doi:10.1016/j.conbuildmat.2006.01.007, 2007.

Ghosh, K. K. and Vistasp, M. K.: Evaluation of strengthening through laboratory testing of FRP rehabilitated bridge decks after in-service loading, Compos. Struct., 77, 206-222, doi:10.1016/j.compstruct.2005.07.014, 2007.
Kim, Y. J. and Harries, K. A.: Modeling of timber beams strengthened with various CFRP composites, Eng. Struct., 32, 32253234, doi:10.1016/j.engstruct.2010.06.011, 2010.

Krishnan, S.: Three-dimensional nonlinear analysis of tall irregular steel buildings subject to strong ground motion, Ph. D Thesis, California Institute of Technology, 2004.

Mortezaei, A., Ronagh, H. R., and Kheyroddin, A.: Seismic evaluation of FRP strengthened RC buildings subjected to near-fault ground motions having fling step, Compos. Struct., 92, 12001211, doi:10.1016/j.compstruct.2009.10.017, 2010.

Mosallam, A. S.: Out-of-plane flexural behavior of unreinforced red brick walls strengthened with FRP composites, Compos. Part B-Eng., 38, 559-574, doi:10.1016/j.compositesb.2006.07.019, 2007.

PEER (Pacific Earthquake Engineering Research Centre): http: //peer.berkeley.edu/smcat/search.html, 2011.

Stierwalt, D. D. and Hamilton, H. R.: Creep of concrete masonry walls strengthened with FRP composites. Constr. Build. Mater., 19, 181-187, doi:10.1016/j.conbuildmat.2004.07.001, 2005.

Tao, Y., Stratford, T. J., and Chen, J. F.: Behavior of a masonry arch bridge repaired using fibre-reinforced polymer composites, Eng. Struct., 33, 1594-1606, doi:10.1016/j.engstruct.2011.01.029, 2011.

Zaki, M. K.: Investigation of FRP strengthened circular columns under biaxial bending, Eng. Struct., 33, 1666-1679, doi:10.1016/j.engstruct.2011.02.003, 2011. 